\title{
Identification of flowering genes in strawberry, a perennial SD plant Katriina Mouhu ${ }^{\dagger 1,2}$, Timo Hytönen* ${ }^{* 1,3}$, Kevin Folta ${ }^{4}$, Marja Rantanen ${ }^{1}$, Lars Paulin ${ }^{5}$, Petri Auvinen ${ }^{5}$ and Paula Elomaa ${ }^{1}$
}

\begin{abstract}
Address: ${ }^{1}$ Department of Applied Biology, PO Box 27, FIN-00014 University of Helsinki, Helsinki, Finland, ${ }^{2}$ Finnish Graduate School in Plant Biology, PO Box 56, FIN-00014 University of Helsinki, Helsinki, Finland, 3Viikki Graduate School in Biosciences, PO Box 56, FIN-00014 University of Helsinki, Helsinki, Finland, ${ }^{4}$ Horticultural Sciences Department, University of Florida, Gainesville, FL, USA and ${ }^{5}$ Institute of Biotechnology, PO Box 56, FIN-00014 University of Helsinki, Helsinki, Finland

Email: Katriina Mouhu - katriina.mouhu@helsinki.fi; Timo Hytönen* - timo.hytonen@helsinki.fi; Kevin Folta - kfolta@ifas.ufl.edu; Marja Rantanen - marja.rantanen@helsinki.fi; Lars Paulin - lars.paulin@helsinki.fi; Petri Auvinen - petri.auvinen@helsinki.fi; Paula Elomaa - paula.elomaa@helsinki.fi

* Corresponding author †Equal contributors
\end{abstract}

Published: 28 September 2009

BMC Plant Biology 2009, 9:122 doi:10.1 186/147/-2229-9-122
Received: 10 December 2008

Accepted: 28 September 2009

This article is available from: http://www.biomedcentral.com//47/-2229/9/122

(C) 2009 Mouhu et al; licensee BioMed Central Ltd.

This is an Open Access article distributed under the terms of the Creative Commons Attribution License (http://creativecommons.org/licenses/by/2.0), which permits unrestricted use, distribution, and reproduction in any medium, provided the original work is properly cited.

\begin{abstract}
Background: We are studying the regulation of flowering in perennial plants by using diploid wild strawberry (Fragaria vesca L.) as a model. Wild strawberry is a facultative short-day plant with an obligatory short-day requirement at temperatures above $15^{\circ} \mathrm{C}$. At lower temperatures, however, flowering induction occurs irrespective of photoperiod. In addition to short-day genotypes, everbearing forms of wild strawberry are known. In 'Baron Solemacher' recessive alleles of an unknown repressor, SEASONAL FLOWERING LOCUS (SFL), are responsible for continuous flowering habit. Although flower induction has a central effect on the cropping potential, the molecular control of flowering in strawberries has not been studied and the genetic flowering pathways are still poorly understood. The comparison of everbearing and short-day genotypes of wild strawberry could facilitate our understanding of fundamental molecular mechanisms regulating perennial growth cycle in plants.

Results: We have searched homologs for 118 Arabidopsis flowering time genes from Fragaria by EST sequencing and bioinformatics analysis and identified 66 gene homologs that by sequence similarity, putatively correspond to genes of all known genetic flowering pathways. The expression analysis of 25 selected genes representing various flowering pathways did not reveal large differences between the everbearing and the short-day genotypes. However, putative floral identity and floral integrator genes API and $L F Y$ were co-regulated during early floral development. API mRNA was specifically accumulating in the shoot apices of the everbearing genotype, indicating its usability as a marker for floral initiation. Moreover, we showed that flowering induction in everbearing 'Baron Solemacher' and 'Hawaii-4' was inhibited by short-day and low temperature, in contrast to short-day genotypes.

Conclusion: We have shown that many central genetic components of the flowering pathways in Arabidopsis can be identified from strawberry. However, novel regulatory mechanisms exist, like SFL that functions as a switch between short-day/low temperature and long-day/high temperature flowering responses between the short-day genotype and the everbearing 'Baron Solemacher'. The identification of putative flowering gene homologs and API as potential marker gene for floral initiation will strongly facilitate the exploration of strawberry flowering pathways.
\end{abstract}




\section{Background}

Transition from vegetative to reproductive growth is one of the most important developmental switches in plant's life cycle. In annual plants, like Arabidopsis, flowering and consequent seed production is essential for the survival of the population until the following season. To assure timely flowering in various environments, Arabidopsis utilizes several genetic pathways that are activated by various external or internal cues. Light and temperature, acting through photoperiod, light quality, vernalization and ambient temperature pathways, are the most important environmental factors regulating flowering time [1]. Moreover, gibberellin (GA) and autonomous pathways promote flowering by responding to internal cues [2,3]. In contrast to annual plants, the growth of perennials continues after generative reproduction, and the same developmental program is repeated from year to year. Regulation of generative development in these species is even more complex, because other processes like juvenility, winter dormancy and chilling are tightly linked to the control of flowering time.

In Arabidopsis photoperiodic flowering pathway, phytochrome (phy) and cryptochrome (cry) photoreceptors perceive surrounding light signals and reset the circadian clock feedback loop, including TOC1 (TIMING OF CAB EXPRESSION), CCA1 (CIRCADIAN CLOCK ASSOCIATED 1) and LHY (LATE ELONGATED HYPOCOTYL) [47]. The central feature in the photoperiodic flowering is the clock generated evening peak of CO (CONSTANS) gene expression [8]. In long-day (LD) conditions, CO peak coincidences with light resulting in accumulation of $\mathrm{CO}$ protein in the leaf phloem and consequent activation of the expression of FT (FLOWERING LOCUS T) [9]. FT protein, in turn, moves to the shoot apex, and together with FD triggers floral initiation by activating floral identity gene AP1 (APETALA 1) [10,11]. FT, together with SOC1 (SUPPRESSOR OF OVEREXPRESSION OF CONSTANS 1) and LFY (LEAFY) form also convergence points for different flowering pathways, and therefore are called flowering integrator genes [12].

In winter-annual ecotypes of Arabidopsis, MADS-box gene FLC (Flowering Locus C) prevents flowering by repressing FT and SOC1, and vernalization is needed to nullify its function [13]. The major activator of FLC is FRI (FRIGIDA) [14], but several other proteins, including for example FRL1 (FRIGIDA-LIKE 1) [15], PIE (PHOTOPERIOD INDEPENDENT EARLY FLOWERING 1) [16], ELF7 and ELF8 (EARLY FLOWERING 7 and 8) [17], and VIP3 (VERNALIZATION INDEPENDENCE 3) [18] are also needed to maintain high FLC expression. During vernalization, FLC is down-regulated by VRN2-PRC2 (Vernalization 2 Polycomb Repressive Complex 2) protein complex containing low temperature activated VIN3 (VERNALIZATION INSENSITIVE3), allowing plants to flower $[19,20]$.
Autonomous and GA pathways respond to endogenous cues to regulate flowering time. The role of the autonomous pathway is to promote flowering by lowering the basal level of FLC transcription [3]. Autonomous pathway consists of few sub-pathways, which include for example RNA processing factors encoded by FCA, FPA, FLK (FLOWERING LOCUS K), FY and LD (LUMINIDEPENDENS) [21], putative histone demethylases $L D L 1$ and LDL2 (LSD1-LIKE 1 and 2) [22], and deacetylases FLD (Flowering locus D) and FVE $[23,24]$. GA pathway is needed to induce LFY transcription and flowering in short-day (SD) conditions [25].

Strawberries (Fragaria sp.) are perennial rosette plants, belonging to the economically important Rosaceae family. Most genotypes of garden strawberry (Fragaria $\times$ ananassa Duch.) and wild strawberry (F. vesca L.) are Junebearing SD plants, which are induced to flowering in decreasing photoperiod in autumn $[26,27]$. In some genotypes, flowering induction is also promoted by decreasing temperatures that may override the effect of the photoperiod $[27,28]$. In contrast to promotion of flowering by decreasing photoperiod and temperature, these "autumn signals" have opposite effect on vegetative growth. Petiole elongation decreases after a few days, and later, around the floral transition, runner initiation ceases and branch crowns are formed from the axillary buds of the crown $[29,30]$. Crown branching has a strong effect on cropping potential as it provides meristems that are able to initiate inflorescences [31].

In addition to SD plants, everbearing (EB) genotypes are found in garden strawberry and in wild strawberry [29,32]. Environmental regulation of induction of flowering in EB genotypes has been a topic of debate for a long time. Several authors have reported that these genotypes are day-neutral $[29,33]$. Recent findings, however, show that long-day (LD) accelerates flowering in several EB Fragaria genotypes $[34,35]$. Interestingly, in wild strawberry genotype 'Baron Solemacher' recessive alleles of SFL gene locus (SEASONAL FLOWERING LOCUS) have been shown to cause EB flowering habit [36]. SFL has not been cloned, but it seems to encode a central repressor of flowering in wild strawberry. Consistent with the repressor theory, LD grown strawberries have been shown to produce a mobile floral inhibitor that is able to move from mother plant to the attached runner plant [37]. GA is one candidate corresponding to this inhibitor, since exogenously applied GA has been shown to repress flowering in strawberries [38,39].

Identification of central genes regulating flowering time and EB flowering habit, as well as those controlling other processes affecting flowering, is an important goal that would greatly accelerate breeding of strawberry and other soft fruit and fruit species of Rosaceae family. In this 
paper, we have searched Fragaria homologs with the known Arabidopsis flowering time genes by EST sequencing and bioinformatics analysis. Dozens of putative flowering genes corresponding to all known genetic pathways regulating flowering time were identified. The expression analysis of several candidate flowering time genes revealed only few differences between the SD and EB wild strawberries, including the presence or absence of AP1 mRNA in the apices of EB and SD genotypes, respectively. Our data provides groundwork for detailed studies of flowering time control in Fragaria using transcriptomics, functional genomics and QTL mapping.

\section{Results}

\section{Environmental regulation of flowering in two EB} genotypes of wild strawberry

We studied the effect of photoperiod and temperature on flowering time in two EB genotypes, 'Baron Solemacher', which contains recessive alleles in SFL locus $[40,41]$, and 'Hawaii- 4 '. Flowering time was determined by counting the number of leaves in the main crown before formation of the terminal inflorescence. In SD genotypes of the wild strawberry, SD $(<15 \mathrm{~h})$ or, alternatively, low temperature $\left(\sim 10^{\circ} \mathrm{C}\right)$ is needed to induce flowering [27]. In EB genotypes 'Baron Solemacher' and 'Rugen', instead, LD and high temperature has been shown to accelerate generative development [35], but careful analysis of the environmental regulation of flowering induction has so far been lacking.

Both 'Baron Solemacher' and 'Hawaii-4' produced five to six leaves in $\mathrm{LD}$ at $18^{\circ} \mathrm{C}$ before the emergence of the terminal inflorescence showing that they are very early-flowering in favorable conditions (Figure $1 \mathrm{~A}$ and $1 \mathrm{~B}$ ). In 'Baron Solemacher', low temperature $\left(11^{\circ} \mathrm{C}\right)$ or SD treatment for five weeks at $18^{\circ} \mathrm{C}$ clearly delayed flowering, but low temperature did not have an additional effect on flowering time in SD. Also in 'Hawaii-4', SD and low temperature delayed flowering, but all treatments differed from each other. Compared to the corresponding LD treatment, $\mathrm{SD}$ at $18^{\circ} \mathrm{C}$ doubled the number of leaves, and low temperature $\left(11^{\circ} \mathrm{C}\right)$ delayed flowering time by about three leaves in both photoperiods. Thus, flowering induction in these EB genotypes is oppositely regulated by photoperiod and temperature than previously shown for the SD genotypes [27].

\section{Construction and sequencing of subtracted cDNA libraries}

We constructed two subtracted cDNA libraries from LD grown EB genotype 'Baron Solemacher' and SD genotype, in order to identify differentially expressed flowering time genes in these genotypes. Plants were grown in LD conditions, where the SD genotype stays vegetative and the $\mathrm{EB}$ plants show early flowering. Pooled shoot apex sample covering the floral initiation period was collected from the EB genotype, and vegetative apices of the same age were
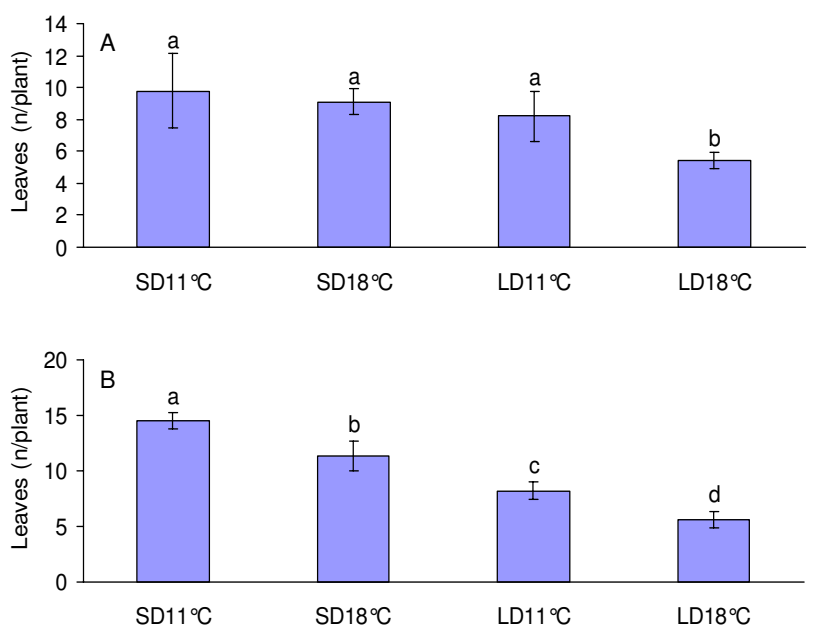

\section{Figure I}

Environmental regulation of flowering in everbearing wild strawberries. The effect of photoperiod (SD 12 h, LD $18 \mathrm{~h})$ and temperature $\left(1 \mathrm{I} / 18^{\circ} \mathrm{C}\right)$ on the flowering time of 'Baron Solemacher' (A) and 'Hawaii-4' (B). Seeds were germinated in $L D$ at $18^{\circ} \mathrm{C}$, and seedlings were exposed to the treatments for five weeks, when the cotyledons were opened. After treatments, plants were moved to $L D$ at $18^{\circ} \mathrm{C}$ and flowering time was recorded as number of leaves in the main crown before the terminal inflorescence. Values are mean \pm SD. Pairwise comparisons between the treatments were done by Tukey's test, and statistically significant differences $(p \leq 0.05)$ are denoted by different letters above the error bars.

sampled from the SD genotype. Suppression subtractive hybridization (SSH), the method developed for extraction of differentially expressed genes between two samples [42], was used to enrich either flowering promoting or flowering inhibiting transcripts from $\mathrm{EB}$ and SD genotypes, respectively.

A total of 1172 ESTs was sequenced from the library enriched with the genes of the SD genotype (SD library subtracted with EB CDNA) and 1344 ESTs from the library enriched with the EB genes (EB library subtracted with CDNA of the SD genotype). 970 SD ESTs [Genbank:GH202443-GH203412] and 1184 EB ESTs [GenBank:GH201259-GH202442] passed quality checking. Pairwise comparison of these EST datasets revealed that there was very little overlap between the libraries. However, general distribution of the sequences to functional categories (FunCat classification) did not reveal any major differences between the two libraries (Additional file 1).

BLASTx searches against Arabidopsis, Swissprot and nonredundant databases showed that over $70 \%$ of the ESTs gave a match in one or all of the three databases (Table 1). Moreover, tBLASTx comparison with different genomes 
Table I: The comparison of $F$. vesca ESTs with different databases.

\begin{tabular}{|c|c|c|c|c|c|}
\hline & & \multicolumn{2}{|c|}{ WT } & \multicolumn{2}{|c|}{ EB } \\
\hline & & number & average length & number & average length \\
\hline \multirow[t]{4}{*}{ A) } & Raw & 1172 & 946 & 1344 & 965 \\
\hline & Poor Quality & 202 & 1037 & 160 & 1066 \\
\hline & Singletons/ESTs & 970 & 452 & 1184 & 451 \\
\hline & & number & $\%$ & number & $\%$ \\
\hline \multirow[t]{4}{*}{ B) } & Arabidopsis & 695 & 72 & 781 & 66 \\
\hline & Swissprot & 483 & 50 & 570 & 48 \\
\hline & Non-redundant & 749 & 77 & 852 & 72 \\
\hline & In all 3 datab. & 752 & 78 & 862 & 73 \\
\hline \multirow[t]{4}{*}{ C) } & Malus & $74 I$ & 76 & 874 & 74 \\
\hline & Oryza & 689 & 71 & 807 & 68 \\
\hline & Vitis & 666 & 69 & 761 & 64 \\
\hline & Populus & 829 & 85 & 928 & 78 \\
\hline \multirow[t]{2}{*}{ D) } & No protein hits & 218 & 22 & 322 & 27 \\
\hline & No Fragaria hits & 370 & 38 & 454 & 38 \\
\hline
\end{tabular}

Average numbers, lengths and percentages of ESTs from EB and SD genotypes. A) numbers and average lengths of raw and poor quality ESTs, and singletons, B) numbers and percentages of BLASTx hits against protein databases, C) numbers and percentages of tBLASTx hits against TIGR plant transcript assemblies of Malus $x$ domestica, Oryza sativa and Vitis vinifera and against Populus genome database, D) numbers and percentages of novel ESTs.

revealed highest number of hits with Populus trichocarpa (Table 1). We also performed tBLASTx searches against TIGR plant transcript assemblies of Malus $\times$ domestica, Oryza sativa and Vitis vinifera and found hits for $64-76 \%$ of ESTs in these assemblies. Finally, the comparison of our sequences with a current Fragaria unigene list at the Genome Database for Rosaceae (GDR) showed that $38.2 \%$ of our ESTs are novel Fragaria transcripts. Taken together, depending on the analysis, $15-22 \%$ of sequences from SD genotype and 22-27\% of EB sequences encode novel proteins, or originate from untranslated regions of mRNA. Moreover, the high number of novel Fragaria sequences in our libraries indicates that SSH method efficiently enriched rare transcripts in the libraries.

\section{Identification of flowering time genes}

Flowering related genes were identified from our libraries by BLASTx searches as described above and fourteen putative flowering time regulators were identified; four gene homologs were present only in EB library, eight in SD library, and two genes in both libraries. In figure 2, we have summarized the Arabidopsis flowering pathways and highlighted the putative homologous genes identified from our EST collection. In general, candidate genes for all major pathways were identified. In addition, 118 Arabidopsis flowering time genes were used as a query to search publicly available GDR Fragaria EST and EST contig databases using tBLASTn. Sequences passing cut-off value of

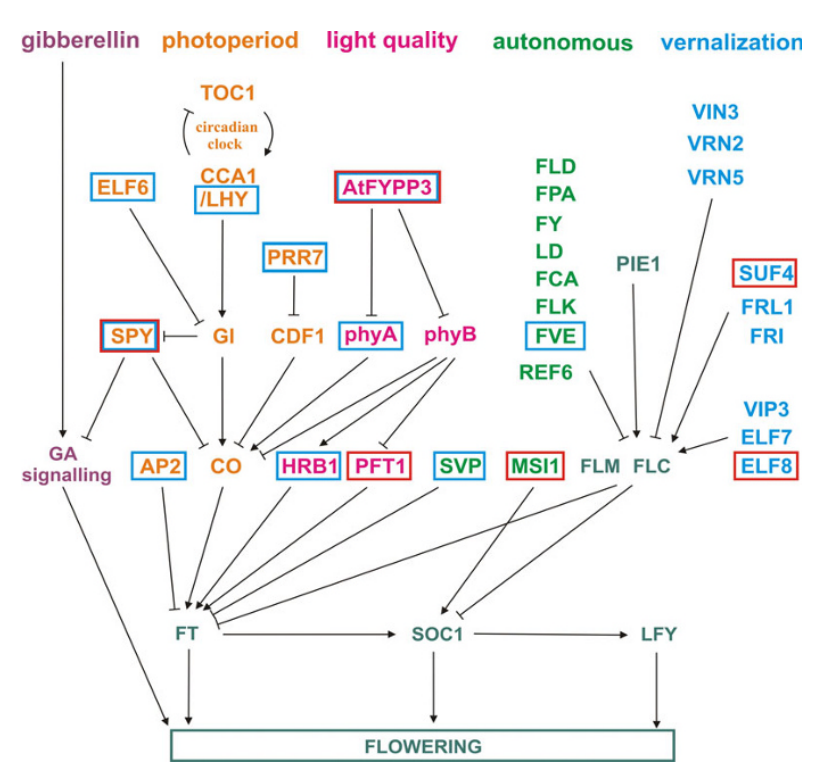

Figure 2

A simplified chart showing Arabidopsis flowering pathways and corresponding gene homologs in Fragaria. Gene homologs found in CDNA libraries produced from SD and EB genotypes are surrounded by blue and red boxes, respectively. Arrows indicate positive regulation and bars negative regulation. 
1e-10 were further analysed by BLASTx algorithm against Arabidopsis protein database, and those returning original Arabidopsis protein were listed. Moreover, sequences that were absent from Fragaria databases were similarly searched from GDR Rosaceae EST database. In these searches, 52 additional Fragaria sequences were identified. Moreover, the total number of 88 homologs of Arabidopsis flowering time genes were found among all available Rosaceae sequences (Additional file 2).

Most genes of the Arabidopsis photoperiodic pathway were found also in Fragaria, and some of the lacking genes were present among Rosaceae ESTs (Table 2, Additional file 2).
We found several genes encoding putative Fragaria photoreceptor apoproteins including phyA, phyC, cry2, ZTL (ZEITLUPE) and FKF1 (FLAVIN BINDING KELCH REPEAT F-BOX 1) [43]. Of the central circadian clock genes, homologs of $L H Y$ and TOC1 $[5,7]$ were present in our EST libraries and GDR, respectively, but CCA1 [6] was lacking from both Fragaria and Rosaceae databases. Furthermore, a putative Fragaria $\mathrm{CO}$ from the flowering regulating output pathway has been cloned earlier [44]. Among the regulators of $\mathrm{CO}$ transcription and protein stability, GI (GIGANTEA) [45] was identified from Rosaceae and putative COP1, SPA3 and SPA4 $[46,47]$ from Fragaria. In addition to genes of the photoperiodic pathway,

Table 2: The list of genes belonging to the photoperiodic flowering pathway.

\begin{tabular}{|c|c|c|c|c|c|c|}
\hline Gene & AT gene locus & Biological function & Act./Repr. +/- & Reference & Fragaria & E-value \\
\hline \multicolumn{7}{|c|}{ Photoreceptors and clock input } \\
\hline PhyA & ATIG09570 & Red light photoreceptor & + & [78] & VES-002-C06 & $5 E-33$ \\
\hline PhyB & AT2GI8790 & Red light photoreceptor & - & [79] & $\mathrm{nf}$ & \\
\hline CRYI & AT4G08920 & Blue light photoreceptor & + & [79] & nf & \\
\hline CRY2 & ATIG04400 & Blue light photoreceptor & + & [79] & DY669844 & $2 \mathrm{E}-110$ \\
\hline ZTL & AT5G57360 & F-box protein/blue light photoreceptor & + & [80] & EX668764 & $2 \mathrm{E}-97$ \\
\hline FKFI & ATIG68050 & F-box protein/blue light photoreceptor & + & {$[65]$} & DY67II70 & $2 \mathrm{E}-54$ \\
\hline ELF3 & AT2G25920 & Unknown & - & {$[60]$} & DY675323 & $3 E-33$ \\
\hline FYPP3 & ATIG50370 & Ser/Thr-specific protein phosphatase $2 \mathrm{~A}$ & - & {$[81]$} & BAR-009-A02 & IE-56 \\
\hline SRRI & AT5G59560 & Unknown & - & [82] & CO8I7759 & IE- 10 \\
\hline \multicolumn{7}{|c|}{ Circadian clock } \\
\hline LHY & ATIG0I060 & Myb domain TF & - & [7] & VES-005-E09 & $9 \mathrm{E}-19$ \\
\hline CCAI & AT2G46830 & Myb domain TF & - & [6] & nf & \\
\hline TOCI & AT5G6I380 & Pseudo-response regulator & - & [5] & DY673/34 & IE-75 \\
\hline LUX & AT3G46640 & Myb TF & - & [83] & DY6685I6 & $3 E-43$ \\
\hline ELF4 & AT2G40080 & Unknown & - & [84] & EX674323 & $2 \mathrm{E}-25$ \\
\hline $\mathrm{Gl}$ & ATIG22770 & Unknown & + & {$[45]$} & nf & \\
\hline PRR5 & AT5G24470 & Pseudo-response regulator & + & {$[85]$} & DY676242 & $3 E-56$ \\
\hline PRR7 & AT5G028I0 & Pseudo-response regulator & + & [85] & VES-0|3-D I 2 & $5 \mathrm{E}-52$ \\
\hline ELF6 & AT5G04240 & Jumonji/zinc finger-class TF & - & {$[86]$} & VES-002-F05 & $\mathrm{IE}-45$ \\
\hline \multicolumn{7}{|c|}{ Output pathway } \\
\hline $\mathrm{CO}$ & AT5GI5840 & putative zinc finger TF & + & [8] & DY672035 & $2 \mathrm{E}-45$ \\
\hline CDFI & AT5G62430 & & - & {$[65]$} & nf & \\
\hline FT & ATIG65480 & Phosphatidylethanolamine binding & + & {$[11]$} & nf & \\
\hline TFLI & AT5G03840 & Phosphatidylethanolamine binding & - & {$[87]$} & nf & \\
\hline FD & AT4G35900 & bZIP TF & + & {$[10]$} & EX675574 & $2 \mathrm{E}-\mathrm{I} 4$ \\
\hline COPI & AT2G32950 & E3 ubiquitin ligase & - & {$[46]$} & DY667888 & IE-94 \\
\hline SPAI & AT2G46340 & WD domain protein & - & [47] & nf & \\
\hline SPA3 & AT3GI5354 & WD domain protein & - & {$[47]$} & DY671873 & $3 E-24$ \\
\hline SPA4 & ATIG53090 & WD domain protein & - & {$[47]$} & DY67I 245 & $2 \mathrm{E}-83$ \\
\hline $\mathrm{RFI} 2$ & AT2G47700 & RIng domain zinc finger & - & [88] & nf & \\
\hline HAP3b & AT5G47640 & CCAAT-binding TF & + & [89] & EX658204 & $2 \mathrm{E}-60$ \\
\hline
\end{tabular}

The most important genes belonging to the photoperiodic pathway in Arabidopsis and their biological function are presented. Floral activators and repressors are indicated by + and - marks, respectively. Moreover, the presence or absence of homologous sequence in Fragaria sequence databases and E-value of BLASTx comparison against Arabidopsis are indicated. Sequences found in our libraries are named BAR and VES for everbearing genotype 'Baron Solemacher' and short-day genotype, respectively. Other ESTs and EST contigs are found from Genome Database for Rosaceae http://www.bioinfo.wsu.edu/gdr/. More complete list is available in Additional file 2. 
homologs for both known sequences belonging to light quality pathways, PFT1 (PHYTOCHROME AND FLOWERING TIME 1) and HRB1 (HYPERSENSITIVE TO RED AND BLUE 1) $[48,49]$, were found from our EST libraries.

For the vernalization pathway, we were not able to find FLC-like sequences from our EST libraries or public Fragaria or Rosaceae EST databases by tBLASTn searches although we used the FLC and FLC-like sequences from Arabidopsis (MAF1-MAF5, MADS AFFECTING FLOWERING 1-5) and several other plant species as query sequences [13,50,51]. Similarly, also FRI [14] was lacking from Rosaceae ESTs but putative FRL (FRIGIDA-LIKE) [15] sequences were identified in Fragaria. In addition, we identified several gene homologs belonging to the FRI complex as well as other regulatory complexes (SWR1, PAF) involved in promoting the expression of FLC (Table 3 , Additional file 2) $[17,52,53]$. Also putative members of FLC repressing PRC2 complex, were present in strawberry ESTs. These include putative VIN3 (VERNALIZATION INSENSITIVE 3) $[19,20]$ that has been identified earlier [54], and putative SWN1 (SWINGER 1), FIE (FERTILIZATION INDEPENDENT ENDOSPERM), VRN1 (VERNALIZATION 1) and LHP1 (LIKE HETEROCHROMATIN PROTEIN 1) $[19,55,56]$, which were found in this investigation (Table 3, Additional file 2). However, putative VRN2 that is needed for the repression of FLC by PRC2 was not found [19].

Table 3: The list of genes belonging to the vernalization pathway.

\begin{tabular}{|c|c|c|c|c|c|c|}
\hline Gene & AT gene locus & Biological function & Act./Repr. +/- & Reference & Fragaria & E-value \\
\hline FLC & AT5GI0I40 & MADS-box TF & - & [13] & nf & \\
\hline MAFI/FLM & ATIG77080 & MADS-box TF & - & {$[50]$} & nf & \\
\hline \multicolumn{7}{|l|}{ Fri complex } \\
\hline FRI & AT4G00650 & Unknown, enhancer of FLC & - & [14] & nf & \\
\hline FRLI & AT5GI6320 & Unknown, enhancer of FLC & - & [15] & EX686406 & $4 \mathrm{E}-45$ \\
\hline FRL2 & ATIG3I8I4 & Unknown, enhancer of FLC & - & [15] & Contig 4768 & $6 \mathrm{E}-49$ \\
\hline FESI & AT2G33835 & $\mathrm{CCCH}$ zinc finger protein & - & {$[53]$} & nf & \\
\hline SUF4 & ATIG30970 & putative zinc finger containing TF & - & [53] & BAR-003-F06 & $5 E-46$ \\
\hline \multicolumn{7}{|l|}{ Swr complex } \\
\hline PIE & AT3G 12810 & ATP-dependent chromatin-remodelling factor & - & {$[16]$} & nf & \\
\hline SEFI/SWC6 & AT5G37055 & Component of chromatin remodelling complex & - & [52] & DY670674 & $4 \mathrm{E}-70$ \\
\hline ARP6/ESDI & AT3G33520 & Component of chromatin remodelling complex & - & [52] & nf & \\
\hline ATXI & AT2G31650 & Putative SET domain protein & - & {$[90]$} & EX687477 & $4 \mathrm{E}-7 \mathrm{I}$ \\
\hline \multicolumn{7}{|l|}{ Pafl complex } \\
\hline ELF7 & ATIG79730 & RNA polymerase 2 associated factor I -like & - & [17] & nf & \\
\hline ELF8 & AT2G06210 & RNA polymerase 2 associated factor -like & - & [17] & BAR-008-H08 & $3 \mathrm{E}-42$ \\
\hline VIP4 & AT5G6II50 & RNA polymerase 2 associated factor -like & - & [91] & EX660943 & $2 \mathrm{E}-50$ \\
\hline VIP3 & AT4G29830 & RNA polymerase 2 associated factor -like & - & [18] & EX67578I & $7 \mathrm{E}-98$ \\
\hline EFS/SDG8 & ATIG77300 & putative histone $\mathrm{H} 3$ methyltransferase & - & [53] & nf & \\
\hline \multicolumn{7}{|c|}{ VRN2-PRC2 complex } \\
\hline VRN2 & AT4GI6845 & Polycomb group zinc finger & + & [92] & nf & \\
\hline CLF & AT2G23380 & Polycomb group protein & + & [93] & nf & \\
\hline SWNI/EZA & AT4G02020 & Polycomb group protein & + & [93] & EX687655 & $3 \mathrm{E}-1 \mathrm{I} 4$ \\
\hline FIE & AT3G20740 & Polycomb group protein & + & [93] & DY67160I & $|E-||| 2$ \\
\hline VIN3 & AT5G57380 & PHD domain protein & + & {$[20]$} & $\mathrm{CO} 8 \mathrm{I} 680 \mathrm{I}$ & $2 \mathrm{E}-58$ \\
\hline LHPI & AT5GI7690 & epigenetic silencing & + & [56] & DY669633 & $2 \mathrm{E}-40$ \\
\hline VRNI & AT3GI8990 & DNA binding protein & + & [55] & DY670727 & $8 \mathrm{E}-43$ \\
\hline
\end{tabular}

The most important genes belonging to the vernalization pathway in Arabidopsis and their biological function are presented. Floral activators and repressors are indicated by + and - marks, respectively. Moreover, the presence or absence of homologous sequence in Fragaria sequence databases and E-value of BLASTx comparison against Arabidopsis are indicated. Sequences found in our libraries are named BAR and VES for everbearing genotype 'Baron Solemacher' and short-day genotype, respectively. Other ESTs and EST contigs are found from Genome Database for Rosaceae http://www.bioinfo.wsu.edu/gdrl. More complete list is available in Additional file 2. 
In addition to the photoperiod and the vernalization pathways, we searched candidate genes for the autonomous and GA pathways. Several sequences corresponding to Arabidopsis genes from both pathways were identified suggesting the presence of these pathways also in Fragaria (Table 4, Additional file 2). Among these genes we found homologs for Arabidopsis FVE and SVP which have been shown to control flowering in a specific thermosensory pathway [24,57]. Moreover, some additional flowering time regulators that are not placed to any specific pathway were identified (Table 4, Additional file 2).

\section{Identification of floral integrator genes in Fragaria}

Sequencing of our EST collections did not reveal any homologs for the floral integrator or identity genes such as $F T$, SOC1, LFY or AP1 [12,58]. A full-length cDNA sequence of SOC1 homolog [GenBank:F5331999] and a 713 bp 3'-end fragment of putative LFY [GenBank:[F]532000] were isolated using PCR. Closest protein homolog of the putative FvSOC1 was 72\% identical Popu- lus trichocarpa MADS5, and the putative FvLFY showed highest amino acid identity (79\%) to Malus domestica FL2. Comparison to Arabidopsis showed that AtSOC1 and AtLFY, respectively, were $66 \%$ and $75 \%$ identical with the corresponding wild strawberry protein sequences (Figure $3 \mathrm{~A}$ and $3 \mathrm{~B}$ ). FT homolog, instead, was not identified in Fragaria despite of many attempts using degenerate PCR and screening of cDNA library plaques and E.coli clones from a variety of tissues and developmental conditions with the Arabidopsis coding sequence (K. Folta, unpublished). However, a putative FT was found in Prunus and Malus protein databases at NCBI. Among the other genes belonging to the same gene family, homologs of MFT (MOTHER OF FT AND TFL1) and ATC (ARABIDOPSIS CENTRORADIALIS) [59] were present in GDR Fragaria EST. Moreover, an EST contig corresponding to the floral identity gene AP1 was found. The length of the translated protein sequence of $F v A P 1$ was 284 amino acids, being 30 amino acids longer than the corresponding Arabidopsis sequence. However, FvAP1 EST contig contained an

Table 4: The list of genes belonging to autonomous and gibberellin flowering pathways.

\begin{tabular}{|c|c|c|c|c|c|c|}
\hline Gene & AT gene locus & Biological function & Act./Repr. +/- & Reference & Fragaria & E-value \\
\hline \multicolumn{7}{|c|}{ Autonomous pathway } \\
\hline FCA & AT4GI6280 & RRM-type RNA binding domain containing & + & [94] & nf & \\
\hline FPA & AT2G434I0 & RRM-type RNA binding domain containing & + & {$[95]$} & nf & \\
\hline FLK & AT3G04610 & $\mathrm{KH}$-type RNA binding domain containing & + & {$[96]$} & EX668302 & $5 E-52$ \\
\hline FY & AT5G I 3480 & mRNA 3' end processing factor & + & {$[97]$} & EX659635 & $5 E-75$ \\
\hline SKBI & AT4G3II20 & Arginine methyltransferase & + & [98] & $\mathrm{nf}$ & \\
\hline FVE & AT2G19520 & retinoblastoma associated & + & {$[24]$} & VES-00I-B03 & $3 E-76$ \\
\hline LD & AT4G02560 & DNA/RNA binding homeodomain protein & + & [99] & DY670534 & $3 E-49$ \\
\hline FLD & AT3G 10390 & component of histone deacetylase complex & + & [23] & nf & \\
\hline LDLI/SWPI & ATIG62830 & Histone H3-Lys 4 demetylase-like & + & {$[22]$} & Contig 2573 & $2 \mathrm{E}-27$ \\
\hline LDL2 & AT3GI3682 & Histone H3-Lys 4 demetylase-like & + & {$[22]$} & DY669828 & $\mathrm{IE}-42$ \\
\hline \multicolumn{7}{|c|}{ Gibberellin pathway } \\
\hline GAl & ATIGI4920 & putative transcriptional repressor & - & {$[100]$} & Contig 3276 & $3 \mathrm{E}-147$ \\
\hline RGA & AT2G0I570 & putative transcriptional repressor & - & {$[100]$} & DQ195503 & $8 E-60$ \\
\hline SPY & AT3GII540 & O-linked $\mathrm{N}$-acetylglucosamine transferase & - & {$[101]$} & BAR-002-C02 & $2 E-93$ \\
\hline DDFI & ATIGI26I0 & AP2-like TF & + & {$[102]$} & Contig 3158 & $5 E-49$ \\
\hline DDF2 & ATIG63030 & AP2-like TF & + & {$[102]$} & $\mathrm{nf}$ & \\
\hline AtMYB33 & AT5G06100 & MYB TF & + & {$[25]$} & DY669997 & $5 E-29$ \\
\hline FPFI & AT5G24860 & Unknown & + & {$[103]$} & Contig 4074 & $7 E-38$ \\
\hline \multicolumn{7}{|l|}{ Other } \\
\hline SVP & AT2G22540 & MADS-box TF & - & {$[57]$} & VES-0I3-D05 & $5 E-22$ \\
\hline AP2 & AT4G36920 & AP2 TF & - & {$[104]$} & VES-008-A07 & $9 \mathrm{E}-16$ \\
\hline PFTI & ATIG25540 & vWF-A domain protein & + & {$[48]$} & BAR-002-D08 & IE-I7 \\
\hline HRBI & AT5G49230 & $\mathrm{ZZ}$ type zinc finger protein & + & [49] & VES-0|2-BOI & $7 E-22$ \\
\hline
\end{tabular}

The most important genes of Arabidopsis autonomous and gibberellin pathways as well as some other floral regulators are presented. The biological function of the genes is indicated, and floral activators and repressors are marked by + and - marks, respectively. Moreover, the presence or absence of homologous sequence in Fragaria sequence databases and E-value of BLASTx comparison against Arabidopsis are indicated. Sequences found in our libraries are named BAR and VES for everbearing genotype 'Baron Solemacher' and short-day genotype, respectively. Other ESTs and EST contigs are found from Genome Database for Rosaceae http://www.bioinfo.wsu.edu/gdr/. More complete list is available in Additional file 2. 
(A)

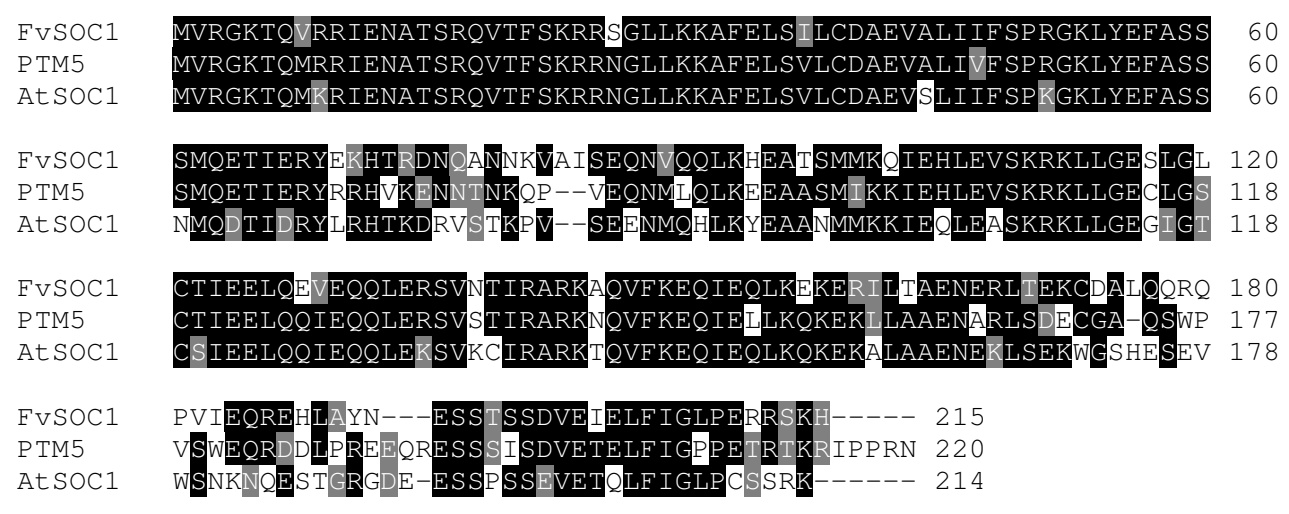

(B)

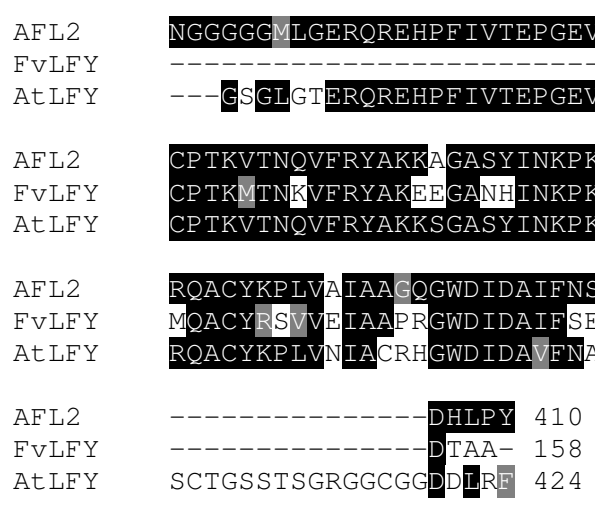

(C)

FVAP 1
$\operatorname{PPAP} 1$

MGRGRVQLKRIENKINRQVTFSKRRSGLLKKAHEISVLCDAEVALIVFSTKGKLFEYSTD 60 MGRGRVQLKRIENKINRQVTFSKRRSGLLKKAQEISVLCDAEVALIVFSTKGKLFEYSTD 60

AtAP 1 MGRGRVQLKRIENK INRQVTFSKRRAGLLKKAHEISVLCDAEVALVVFSHKGKLFEYSTD

FVAP 1

$\operatorname{PPAP} 1$

AtAP 1

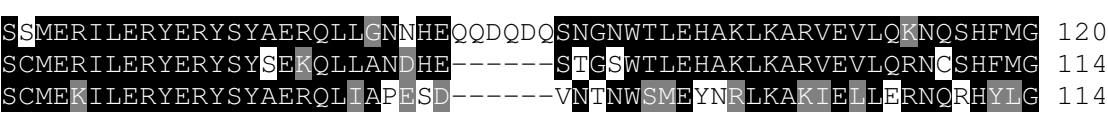

FVAP 1

PPAP 1

AtAP 1

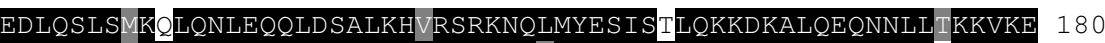

EDLQSLSLKELQNLEQQLDSALKHIRSRKNQVMYES ISELQKKDKALQEQNNLLAKKVKE 174 EDLQAMSPKELQNLEQQLDTALKHIRTRKNQLMYES INELQKKEKAIQEQNSMLSKQIKE 174

FVAP 1

PPAP 1

AtAP 1

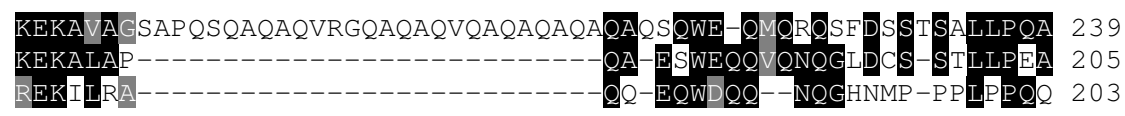

FVAP 1

PPAP 1

AtAP 1

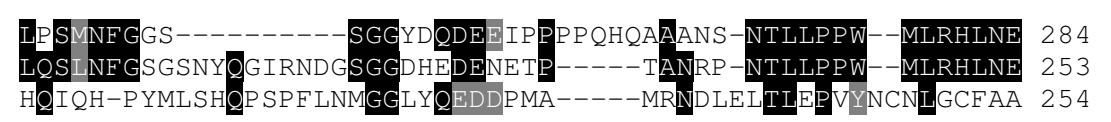

Figure 3

Protein alignments of Fragaria flowering integrator and identity genes. Multiple alignments of Fragaria protein sequences of full length SOCI (A), partial LFY (B) and full-length API (C) with closest protein homologs and corresponding protein sequence of Arabidopsis thaliana. Alignments were done by ClustalW (A, B) or T-Coffee (C) and modified by Boxshade program. F. vesca API protein sequence was translated from GDR Fragaria EST contig 494I. PTM5 = Populus tremuloides MADS5, AFL2 = Apple FLORICAULA 2, PpAPI = putative Prunus persica API. 
unknown sequence stretch of $81 \mathrm{bp}$ at nucleotide position 596-677. Putative FvAP1 showed highest overall identity (68\%) with putative AP1 from Prunus persica (Figure 3C). Moreover, the 5' sequence containing 187 amino acids (the sequence before the unknown part) was 73\% identical with the Arabidopsis AP1.

\section{Gene expression analysis revealed few differences between $E B$ and $S D$ genotypes}

We compared the expression of selected flowering time genes (Table 5) corresponding to each flowering pathway in the leaf and shoot apex samples of EB and SD genotypes in order to explore the role of different pathways. Only few of the analysed genes were differentially expressed between the genotypes. Floral integrator gene $L F Y$ was slightly up-regulated in the shoot apex samples of EB (Table 6). Moreover, PCR expression analysis with two different primer pairs showed that AP1 was specifically expressed in EB apices correlating with the identity of the meristems. Among the genes from different flowering pathways, only two genes, vernalization pathway gene ELF8 [17] and photoperiod pathway gene ELF3 [60], were slightly differentially expressed between the genotypes (Table 6).

\section{Developmental regulation of floral integrator, floral identity, and GA pathway genes}

We analysed the developmental regulation of $A P 1, L F Y$, SOC1, GA3ox and GA2ox transcription in the shoot apices of LD grown plants of EB and SD genotype containing one to four leaves. Ubiquitin, used as a control gene, was stable between different developmental stages, but was amplified $~ 1$ PCR cycle earlier in SD genotype (Additional file 3 ). Thus direct comparison between the genotypes is not possible, but the trends during development are comparable. Three genes, AP1, LFY, and GA3ox, had clear developmental stage dependent expression pattern in EB apices, showing biggest changes after one or two leaf stage (Figure $4)$. The expression of AP1 was detected in EB apices already at one leaf stage, and its mRNA accumulated gradually reaching 6-fold increase at two leaf stage and 50-fold increase at four leaf stage (Figure 4A). In parallel, transcription of LFY started to increase at 2-leaf stage, but the change in its expression was much smaller (Figure 4B). A floral integrator gene, SOC1, in contrast, did not show clear developmental regulation (Figure 4C). Also GA pathway was co-regulated with $A P 1$ and $L F Y$, since GA biosynthetic gene GA3ox was strongly down-regulated after two leaf stage (Figure 4D). In addition, GA catabolism gene, GA2ox, tended to follow changes in the expres-

Table 5: The list of PCR primers used in real-time RT-PCR.

\begin{tabular}{|c|c|c|}
\hline Gene & Forward primer & Reverse primer \\
\hline UBI & CAGACCAGCAGAGGCTTATCTT & TTCTGGATATTGTAGTCTGCTAGGG \\
\hline LFY & CGGCATTACGTTCACTGCTA & CCTGTAACACGCCTGCATC \\
\hline $\mathrm{SOCl}$ & CAGGTGAGGCGGATAGAGAA & AGAGCTTTCCTCTGGGAGAGA \\
\hline API & CGCTCCAGAAGAAGGATAAGG & CATGTGACTGAGCCTGTGCT \\
\hline API & TCTGAAGCACGTAAGGTCTA & ATCCTGATCATAACCTCCAG \\
\hline LHY & AAAGCTGGAGAAGGAGGCAGTC & CCGAGGATAAGGATTGCTTGGT \\
\hline ZTL & TGCATGGGGTAGTGAAACAA & CACCTCCGACAGTGACCTTT \\
\hline FKFI & ACCCACATCGTTTGTGGTCT & ACATCAGGATCCACCAGAGG \\
\hline ELF3 & TCCTCCAAGGAACAAGATGG & CCATTCCССTGATTTGAGAG \\
\hline ELF6 & TTCGAAGGTCTTGGCAATGG & GCGCCTGAGTTTTATCCAACAC \\
\hline COL4 & GACCGAGAAATCCACTCTGC & CTCTCCGTCCGACAAGTAGC \\
\hline CO & GACATCCACTCCGCCAAC & GTGGACCCCACCACTATCTG \\
\hline PFTI & GCGACATGCCAAGGTTAGAATT & TCAGCGCCTCACACTCTTACAC \\
\hline$H R B I$ & GAATGGTGGACATCAGCAATCC & CCTCCGAAAGAATTGCTCAACA \\
\hline FYPP3 & ACAAAATGGCCCСTCATGTG & TGTGCTATGTGTCCATGGTGGT \\
\hline FRL & CGCTAGTCAAGGTCGAGGAG & CGACTTCATCTCCATCAGCA \\
\hline ELF8 & GCTCAGAATGCTCСTCCTGT & TGAGTATTGCAGCCACTTGC \\
\hline VRN5 & AGCCCTTGATGTCATCAGCTG & CCGATGAATGGTTGGCTAATG \\
\hline MSII & TCTCCACACCTTTGATTGCCA & ACACCATCAGTCTCCTGCCAAG \\
\hline LHPI & GGAGAGCCAGAACCAGGAG & СТСАССТТСТТССССТТССТ \\
\hline FVE & GATCCAGCAGCAACCAAGTCTC & CСTCTTGGTGCAACAGAAGGAC \\
\hline SVP & CGTGCTAAGGCAGATGAATGG & TGAAGCACACGGTCAAGACTTC \\
\hline SPY & TGCGGTGTCAAATTGCATCA & GGCAACACTCAAGATGGATTGC \\
\hline GA3ox & ССТСАСААТСАТССАССААТСС & CGCCGATGTTGATCACCAA \\
\hline GA2ox & CACCATGCCCAGAGCTTCA & AGGCCAGAGGTGTTGTTGGAT \\
\hline TFL I & TGCAGAAACAAACGAGTTCGG & CCAAGAGCATCGATCATTTGGT \\
\hline AP2 & CCCGAAATCCTTGATTGTTCC & AACACTGCAATCGAACAACAGC \\
\hline
\end{tabular}

$\mathrm{T}_{\mathrm{m}}$ value of the primers is $60 \pm 1^{\circ} \mathrm{C}$. 
Table 6: The expression of selected genes in the wild strawberry.

\begin{tabular}{lll}
\hline Gene & MSII as a control & FVE as a control \\
\hline Shoot apex samples & & \\
API & Expressed only in EB & Expressed only in EB \\
LFY & $1.8 \pm 0.4$ & $1.9 \pm 0.3$ \\
ELF8 & $1.5 \pm 0.1$ & $1.6 \pm 0.1$ \\
Leaf samples & & \\
ELF3 & $1.5 \pm 0.1$ & $1.8 \pm 0.0$ \\
\hline
\end{tabular}

Relative gene expression in the shoot apex or leaf samples of LD grown plants of EB genotype compared to SD genotype. Ct values of genes of interest were normalized against Ctvalues of MSII and FVE to get normalized $\Delta \mathrm{Ct}$ values. The expression ratios between genotypes $(E B / S D)$ were calculated from the formula $2^{\Delta C t E B} / 2^{\Delta C t S D}$. Values are mean \pm standard deviation. Pooled shoot apex samples and leaf samples at four leaf stage were used.

sion of GA3ox, although the results were not so clear (data not shown). In SD genotype, in contrast, $A P 1$ was absent and other genes did not show clear developmental regulation (Figure 4). In this experiment, control plants of EB
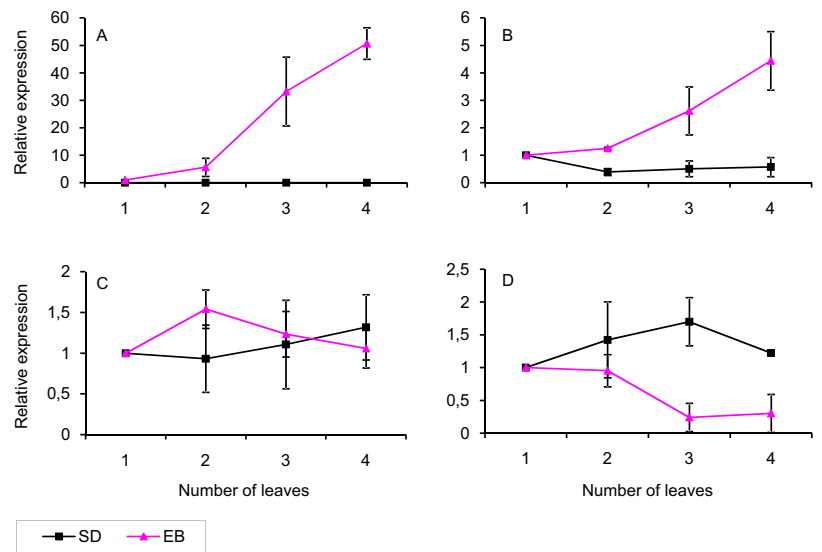

Figure 4

Developmental regulation of gene expression in wild strawberry shoot apices. The expression of $A P I(A), L F Y$ (B), SOCI (C) and GA3ox (D) in the SD and EB ('Baron Solemacher') genotype of the wild strawberry. Triplicate shoot apex samples were collected from LD grown plants at one to four leaf stage. $\mathrm{Ct}$ values were normalized against a Ubiquitin [GenBank:DY672326] gene to get normalized $\Delta \mathrm{Ct}$ values. The expression differences between one leaf stage and later developmental stages were calculated from the formula $2^{\Delta \mathrm{Ct}}$ later developmental stage $/ 2 \Delta \mathrm{Ct}$ one leaf stage. The expression values at one leaf stage were artificially set to I separately for both genotypes. Values are mean \pm SD. Note that Ubiquitin was amplified $\sim$ I cycle earlier in SD genotype, but was stable between different developmental stages. Therefore, expression values between genotypes cannot be directly compared, while the expression levels between the various developmental stages are comparable. genotype flowered very early, after producing $4.7 \pm 0.3$ leaves to the main crown, whereas plants of SD genotype remained vegetative.

\section{Discussion}

\section{Identification of flowering genes in strawberry}

Genetic regulation of flowering in strawberry has earlier been studied only by crossing experiments. According to Weebadde et al. [61], everbearing character is a polygenic trait in garden strawberry whereas other studies indicate the presence of a single dominant gene [62]. Different results may arise from different origin of everbearing habit, since at least three different sources have been used in strawberry breeding $[32,61,62]$. Studies in $F$. vesca 'Baron Solemacher'have shown that EB flowering habit in this genotype is controlled by recessive alleles of a single locus, called seasonal flowering locus (sfl) [40,41]. Identification of central genes regulating flowering, as well as those controlling other processes that affect flowering (runnering, chilling), is an important goal that would greatly accelerate breeding of strawberry and other soft fruit and fruit species of Rosaceae family.

For comprehensive identification of candidate genes of the strawberry flowering pathways, we searched homologs for 118 Arabidopsis flowering time genes from our own cDNA libraries and from GDR. In total, we were able to identify 66 gene homologs among about 53000 EST sequences. Moreover, gene homologs lacking from Fragaria were further mined from Rosaceae EST collections containing about 410000 EST sequences. These searches revealed 22 additional putative flowering time genes in Rosaceae. Ongoing genome sequencing projects in apple, peach and wild strawberry will ultimately reveal the currently lacking flowering regulators in these species [63].

Sequences found in Fragaria corresponded to all known Arabidopsis flowering time pathways [2] suggesting that all of these genetic pathways may be present in Fragaria. However, the sequence conservation does not necessarily mean functional conservation, so major candidate genes from different pathways have to be functionally characterized in order to prove the presence of these pathways in strawberry. Few central regulators of flowering time are lacking from Fragaria sequence collections and some of them also from Rosaceae databases. For example, we were not able to identify a homolog for the florigen gene FT [11] in Fragaria regardless of several different attempts. This is probably due to its low expression level and tissue specific expression pattern [64]. Similarly, GI, which links circadian clock and $\mathrm{CO}[8,65]$, was absent from the Fragaria sequences. FT and GI homologs were, however, found in apple and Prunus, showing that they are present in Rosaceae. Moreover, consistent with studies in model 
legumes [66], CCA1 was lacking in Rosaceae, but its redundant paralog, $L H Y$, is represented by few ESTs in Fragaria. CCA1 and LHY are MYB-type transcription factors which repress the expression of TOC1 in the central loop of Arabidopsis circadian clock [67]. Thus, in Fragaria and other species of Rosaceae family, LHY alone may control the expression of TOC1 in the clock core. This contrasts with other species, like Populus, where duplications of the LHY/CCA1 genes contribute to an apparently more complex mode of clock control [68].

Vernalization pathway in Arabidopsis culminates in FLC and FLC-like floral repressors $[13,50]$. They have been functionally characterized only in Brassicaceae $[13,69]$, although homologous MADS box genes have been recently found from several eudicot lineages by phylogenetic analysis [51]. However, we were not able to identify FLC-like sequences in Rosaceae by using several FLC-like sequences as a query. Similarly, also FRI homologs were lacking from the Rosaceae sequence collections. However, putative homologs of FRI-like genes, FRL1 and FRL2, which are involved in FLC activation in Arabidopsis [15] were found, as well as several other homologs of genes belonging to FLC regulating protein complexes. Despite the presence of these transcripts, the presence of FLC is unclear, since at least PRC2 complex has several target genes [70]. Cloning and characterization of putative FLClike and FRI genes as well as FT in strawberry would greatly expand our understanding of strawberry flowering pathways, and therefore, it is one of the most important targets of further studies. If these transcripts are present in strawberry, it is likely that the precise control of flowering has placed their expression in specific tissues or contexts where they are not easily detected. However, their presence should be substantiated in analysis of the impending genome sequence. Another important goal is the identification of putative Rosaceae or Fragaria specific flowering time genes. Ultimately, transcriptomics studies and functional analysis of central genes may reveal how different flowering pathways, which may be closely related to Arabidopsis pathways, make seasonal flowering in strawberry.

\section{What is the SFL gene?}

SFL is a single dominant locus that enforces seasonal flowering habit in wild strawberry, and homozygous mutation in this locus leads to continuous flowering habit in at least one genotype, 'Baron Solemacher' [36]. In SD genotypes of wild strawberry, SD or low temperature induce flowering [27] probably by overcoming the function of SFL repressor gene. We showed here that EB genotypes 'Baron Solemacher' and 'Hawaii-4' produce only 5 6 leaves to the main crown before the formation of the terminal inflorescence in $\mathrm{LD}$ at $18^{\circ} \mathrm{C}$. Hence, flowering induction in these conditions occurs soon after germination. In SD $(12 \mathrm{~h})$ or at low temperature $\left(11^{\circ} \mathrm{C}\right)$ instead, plants formed several leaves more before the inflorescence. This finding shows that, in contrast to SD genotypes, both SD and low temperature restrain flowering induction in these genotypes, confirming earlier suggestions that EB genotypes of wild strawberry are in fact LD plants [35]. Most simple explanation for these opposite environmental responses is that the lack of flowering inhibitor, produced by active SFL gene, unmasks LD induced flowering promotion pathway in 'Baron Solemacher' and possibly in other EB genotypes. Given that both SD and low temperature repress $S F L$, analogous flowering regulating pathway has not yet been characterized at molecular level.

Our gene expression analysis did not give any hints of the putative location of SFL in wild strawberry flowering pathways. However, homologs of certain flowering repressors can be consireded as candidates for $S F L$, including the rice CO homolog HD1 (HEADING DATE 1), or Arabidopsis vernalization pathway genes FLC and FRI $[13,14,71]$. In strawberry, the role of vernalization pathway remains unclear until the presence or absence of FRI or FLC function is confirmed or other targets for this pathway are found. Strawberry $C O$, instead, has been cloned and mapped in Fragaria reference map, but its position does not match with the genomic location of SFL showing that $C O$ itself is not SFL $[44,72]$. However, the possibility that some regulator of $C O$ transcription or protein stability could be SFL cannot be ruled out and should be studied further.

Exogenously applied GA inhibits flowering in wild strawberry, and therefore, GA has been suggested to be a floral repressor [38,39]. Similar patterns have been observed and delineate differences between recurrent and nonrecurrent roses [73]. However, we did not find clear differences in the expression of GA biosynthetic and catabolism genes, GA3ox and GA2ox, in the shoot apex samples of EB and SD genotypes before the floral initiation had occurred. In contrast, GA3ox was strongly repressed in EB apices after floral initiation and GA2ox showed similar trend. The fact that these changes in GA pathway occurred after two leaf stage suggests that GA signal was regulated during early flower development rather than during floral transition. These data does not support the role of endogenous GA as the regulator of flowering induction, indicating that SFL is not situated in the GA pathway. However, quantitative analysis of GA levels is needed to show whether the observed changes in the expression of GA pathway genes are reflected at the metabolic level.

\section{AP I is a potential marker of floral initiation in strawberry} Gene expression analysis revealed that two putative flowering genes, $A P 1$ and $L F Y$, were co-regulated during floral development in EB wild strawberry. The homolog of floral 
identity gene $A P 1$ was expressed in the EB apex already at one leaf stage, and its expression was strongly enhanced during later developmental stages. Also LFY mRNA accumulated along with AP1 during floral development in EB genotype, whereas SOC1 did not show a clear trend. The mRNA of SOC1 and LFY were present also in SD genotype, but AP1 transcription was not detected. In Arabidopsis, LFY and AP1 activate each other's expression constituting a feedback loop $[12,58]$. Moreover, AP1 is activated by FT-FD heterodimer shortly after flowering induction [10]. Thus, the expression patterns of $A P 1$ and $L F Y$ in the meristems of EB genotype suggest that flowering induction in these plants occurs before two leaf stage in LD conditions. Consistent with this conclusion, flower initials were clearly visible by stereomicroscope in the meristems at three or four leaf stage, and plants flowered after producing on average 4.7 leaves in the main crown. Based on our results, AP1 can be used as a marker for floral initiation in wild strawberry. However, functional studies are needed to confirm the role of AP1, LFY and SOC1 as floral integrator and identity genes, and this approach is currently going on.

\section{Conclusion}

We have explored putative components for the genetic flowering pathways in perennial SD plant wild strawberry by identifying 66 homologs of Arabidopsis flowering time genes. Although few central genes are lacking, these data indicate that all known genetic flowering pathways may be present in Fragaria. This is consistent with the finding that EB genotypes, 'Hawaii-4' and 'Baron Solemacher', show similar environmental regulation of flowering than Arabidopsis summer-annuals. We also studied the expression of selected candidate genes and found that few genes were co-regulated in the shoot apex of the EB genotype during early floral development. Most strikingly, the mRNA of AP1 specifically accumulated in EB genotype, but was absent in SD genotype, showing its usefulness as a marker of floral initiation. Finally, identification of putative flowering time genes reported here enables their transcriptional and functional characterization, as well as genetic mapping, which may give answers for the relative importance of each genetic flowering pathway and lead to cloning of the central repressor gene, SFL. Ultimately, these genetic resources could be utilized in cultivar breeding of various species of Rosaceae family through genetic transformation and marker assisted selection breeding.

\section{Methods}

\section{Plant materials, growing conditions and sampling}

Seeds of SD and EB ('Baron Solemacher') genotypes of the wild strawberry (NCGR accession numbers [PI551792] and [PI551507], respectively) were sown on potting soil mixture (Kekkilä, Tuusula, Finland) and grown in a greenhouse under LD conditions (day length min. $18 \mathrm{~h}$ ), provided by $400 \mathrm{~W}$ SON-T lamps (Airam, Kerava, Finland) and natural sunlight. After two to three leaves had developed per plant, shoot apex samples (tip of the shoot containing the meristem as well as two to three leaf initials) were collected under a stereomicroscope at ten different time points with three days intervals. Samples from each time point were pooled and used for the construction of cDNA libraries and real-time RT-PCR. WT samples contained shoot apices of the main crown, collected from 50 plants per time point. Also in EB genotype, shoot apices of the main crown were collected until the sepal initials became visible in the meristems. After this time point, the apices from one to three side shoots per plant were collected, altogether from 40 plants per sampling. In addition, leaf samples were collected from the same plants at four leaf stage for real-time RT-PCR analysis. Moreover, separate shoot apex samples were collected from WT and EB genotypes at one, two, three and four leaf stages. Control plants were grown in LD and their flowering time was determined by counting the number of leaves in the main crown before the terminal inflorescence. All samples were collected in July - August 2006 - 2008.

\section{Preparation and sequencing of subtracted cDNA libraries}

Total RNA from pooled shoot apex samples was extracted with a pine tree method for RNA isolation [74]. The cDNA was synthesized with BD SMART cDNA Synthesis kit (Clontech, Palo Alto, US), amplified with PCR as instructed for subtraction, purified with Chroma Spin1000 DEPC-H2O Columns (Clontech), extracted with chloroform:isoamylalcohol (24:1) using Phase Loch Gel Heavy $1.5 \mathrm{ml}$ tubes (Eppendorf, Hamburg, Germany), digested with RsaI (Boehringer Mannheim, Mannheim, Germany), and purified with High Pure PCR Product Purification kit (Roche Diagnostics, Indianapolis, US). The cDNAs were subtracted using BD PCR-Select cDNA Subtraction Kit (Clontech) in both forward and reverse directions. The forward and reverse PCR mixtures were digested with RsaI (Boehringer Mannheim) and purified with High Pure PCR Product Purification Kit (Roche). After digestion, A-tailing was done as instructed in the technical manual of pGEM-T and pGEM-T Easy Vector Systems and PCR mixtures were ligated to pGEM-T Easy Vector (Promega, Wisconsis, US), and electroporated to TOP10 cells. The libraries were sequenced at the Institute of Biotechnology, University of Helsinki, as described earlier [75]. 


\section{Bioinformatics analysis}

Raw EST sequences were quality checked before annotation. Base calling, end clipping and vector removal were performed by CodonCodeAligner-software (CodonCode Corporation, US). After this the ESTs were manually checked and sequences that contained poly- $T$ in the beginning followed by short repetitive sequences were removed. BLASTx was performed against functionally annotated Arabidopsis protein database (v211200, MIPS), Swissprot and non-redundant protein database (NCBI), and Populus trichocarpa genome of DOE Joint Genome Institute [76] using cut-off value 1e-10. tBLASTx was performed against TIGR plant transcript assemblies of Malus $x$ domestica, Oryza sativa and Vitis vinifera [77], and GDR Fragaria and Rosaceae Contigs using cut-off value 1e-10. For MIPS BLAST hits corresponding functional classes and Gene Ontology classes were obtained from Functional Classification Catalogue (Version 2.1) and GO annotation for Arabidopsis thaliana (Version 1.1213).

Homologs of Arabidopsis flowering time genes were searched from GDR Fragaria contig and EST databases using tBLASTx algorithm and Arabidopsis protein sequences as a query. Homologous sequences passing a cut-off value 1e-10 were further analysed by BLASTx algorithm against Arabidopsis protein database, and sequences showing highest sequence homology with the corresponding Arabidopsis genes were selected. The sequences lacking from Fragaria were similarly searched from GDR Rosaceae EST database and from Rosaceae protein database at NCBI.

\section{Photoperiod and temperature treatments}

For the analysis of environmental regulation of flowering in EB genotypes, seeds of 'Baron Solemacher', and 'Hawaii-4' were germinated in $18 \mathrm{~h} \mathrm{LD}$ at $18^{\circ} \mathrm{C}$. During germination, plants were illuminated using $400 \mathrm{~W}$ SON-T lamps (Airam) for $12 \mathrm{~h}$ daily $\left(90 \pm 10 \mu \mathrm{mol} \mathrm{m}^{-2} \mathrm{~s}^{-1}\right.$ at plant height plus natural light) and incandescent lamps were used for low-intensity daylength extension $\left(5 \pm 1 \mu \mathrm{mol} \mathrm{m}{ }^{-}\right.$ $2 \mathrm{~s}^{-1}$ at plant height). After opening of the cotyledons plants were moved to four treatments, SD and LD (12/18 h) at low or high temperature $\left(11 / 18^{\circ} \mathrm{C}\right)$, for five weeks. In $\mathrm{LD}$, incandescent lamps were used for low-intensity daylength extension ( $5 \pm 1 \mu \mathrm{mol} \mathrm{m} \mathrm{m}^{-2} \mathrm{~s}^{-1}$ at plant height) after $12 \mathrm{~h}$ main light period. Also photoperiods of 8 and $8+8 \mathrm{~h}(\mathrm{SD} / \mathrm{LD})$ were tested, but because of very slow growth in these light treatments, longer photoperiods were selected (data not shown). SD treatments were carried out at the greenhouse using darkening curtains, while LD treatments (photoperiod $18 \mathrm{~h}$ ) were conducted in a similar greenhouse compartment without curtains. The experiments were carried out during winter 2007 - 2008, when the natural day length was under $12 \mathrm{~h}$. After treatments, plants were potted to $8 \times 8 \mathrm{~cm}$ pots, moved to LD
(18 h), and flowering time was determined as described above.

\section{Gene expression analysis}

Total RNA from leaf and shoot apex samples was extracted with a pine tree method [74], and cDNAs were synthesized from total RNA using Superscript III RT kit (Invitrogen, Carlsbad, US) and $\mathrm{dT}_{18} \mathrm{VN}$ anchor primers. LightCycler 480 SYBR Green I Master kit (Roche Diagnostics, Indianapolis, US) was used to perform $15 \mu$ real-time RT-PCR reactions in 384-well plates according to manufacturer's instructions by using Light Cycler 480 real-time PCR system (Roche Diagnostics). PCR primers with $\mathrm{T}_{\mathrm{m}}$ value of $60^{\circ} \mathrm{C}$ were used (Table 5). Three biological replicates were analysed for shoot apex samples from different developmental stages (Figure 4), and two biological replicates were used for pooled shoot apex and leaf samples (Table 6).

\section{Authors' contributions}

TH, KM and PE designed all experiments. PE coordinated the study and helped to draft the manuscript. TH run the real-time PCR analysis, performed flowering gene searches from sequence databases, and drafted the manuscript together with KM. KM constructed the subtracted cDNA libraries and performed bioinformatics analysis together with KF. KF also helped to draft the manuscript. MR participated in flowering time analysis and sampling of shoot apices. PA and LP were responsible for the EST sequencing. All authors read and approved the final manuscript.

\section{Additional material}

\section{Additional file 1}

Functional classification of ESTs from EB and SD genotypes. The percentage of gene hits in different FunCat classes in two cDNA libraries prepared in this study is shown. Same gene may be classified in one or several classes. WT and EB libraries were prepared from SD and everbearing genotypes, respectively. Click here for file

[http://www.biomedcentral.com/content/supplementary/14712229-9-122-S1.PDF]

\section{Additional file 2}

Complete list of flowering time genes searched. Genes belonging to different flowering pathways are listed in separate sheets of .xls file. Homologous sequences found in Fragaria are indicated. Moreover, corresponding Rosaceae sequences were searched, if Fragaria sequence was not found. GenBank EST sequence number or Genome Database for Rosaceae contig number is given for Fragaria and Rosaceae ESTs and contigs, respectively. Click here for file

[http://www.biomedcentral.com/content/supplementary/14712229-9-122-S2.XLS] 


\section{Additional file 3}

The stability of control genes used in this study. Ct values of FVE, MSI and UBI in the leaf samples collected at four leaf stage (a) and in the pooled shoot apex samples (b). Same plant material of SD and EB ('Baron Solemacher') genotypes was used than in Table 6. Panel c: Ct values of UBI in the shoot apex samples of SD and EB genotypes at different developmental stages. Values are means ( \pm standard deviation) of two $(a, b)$ or three (c) biological and three technical replicates. One g of total RNA was used for cDNA synthesis for each sample. Different Ct values of UBI in shoot apex samples in figures $b$ and $c$ are due to different cDNA dilutions used for PCR.

Click here for file

[http://www.biomedcentral.com/content/supplementary/14712229-9-122-S3.PPT]

\section{Acknowledgements}

Dr. Michael Brosche is acknowledged for his kind help in the production of subtracted cDNA libraries and M.Sc. Techn. Erkko Airo for his valuable technical help. In addition, Finnish Ministry of Agriculture and Forestry is thanked for financial support.

\section{References}

I. Ausín I, Alonso-Blanco C, Martinez-Zapater M: Environmental regulation of flowering. Int J Dev Biol 2005, 49:689-705.

2. Putterill J, Laurie R, Macknight R: It's time to flower: the genetic control of flowering time. Bioessays 2004, 26:363-373.

3. Simpson GG: The autonomous pathway: epigenetic and posttranscriptional gene regulation in the control of Arabidopsis flowering time. Curr Opinion Plant Biol 2004, 7:570-574.

4. Imaizumi T, Kay SA: Photoperiodic control of flowering: not only by coincidence. Trends Plant Sci 2006, I I:550-558.

5. Strayer C, Oyama T, Schultz TF, Raman R, Somers DE, Más P, Panda S, Kreps JA, Kay SA: Cloning of the Arabidopsis clock gene $\mathrm{TOCl}$, an autoregulatory response regulator homolog. SCience 2000, 289:768-77।.

6. Wang ZY, Tobin EM: Constitutive expression of the CIRCADIAN CLOCK ASSOCIATED I (CCAI) gene disrupts circadian rhytms and suppresses its own expression. Cell 1998, 93:1207-1217.

7. Schaffer R, Ramsay N, Samach A, Corden S, Putterill J, Carré IA, Coupland G: The late elongated hypocotyl mutation of Arabidopsis disrupts circadian rhythms and the photoperiodic control of flowering. Cell 1999, 93:1219-1229.

8. Suárez-López P, Wheatley K, Robson F, Onouchi H, Valverde F, Coupland G: CONSTANS mediates between the circadian clock and the control of flowering in Arabidopsis. Nature 200I, 410:1116-1120.

9. Yanovsky MJ, Kay SA: Molecular basis of seasonal time measurement in Arabidopsis. Nature 2002, 419:308-312.

10. Abe M, Kobayashi Y, Yamamoto S, Daimon Y, Yamaguchi A, Ikeda $Y$, Ichinoki $\mathrm{H}$, Notaguchi M, Goto K, Araki T: FD, a bZIP protein mediating signals from the floral pathway integrator FT at the shoot apex. Science 2005, 309:1052-1056.

II. Corbesier L, Vincent C, Jang S, Fornara F, Fan Q, Searle I, Giakountis A, Farrona S, Gissot L, Turnbull C, Coupland G: FT protein movement contributes to long-distance signalling in floral induction of Arabidopsis. Science 2007, 316:1030-1033.

12. Parcy M: Flowering: a time for integration. Int J Dev Biol 2005, 49:585-593.

13. Searle I, He Y, Turck F, Vincent C, Fornara F, Krober S, Amasino RA, Coupland G: The transcription factor FLC confers a flowering response to vernalization be repressing meristem competence and systemic signalling in Arabidopsis. Genes Dev 2006, 20:898-912.

14. Johanson U, West J, Lister C, Michaels S, Amasino R, Dean C: Molecular analysis of FRIGIDA, a major determinant of natural variation in Arabidopsis flowering time. Science 2000 290:344-347.
15. Michaels SD, Bezerra IC, Amasino RM: FRIGIDA-related genes are required for the winter-annual habit in Arabidopsis. PNAS 2004, 10 I:328I-3285.

16. Noh Y, Amasino RS: PIEI, an ISWI family gene, is required for FLC activation and floral repression in Arabidopsis. Plant Cell 2003, I5:167I-1682.

17. He Y, Doyle MR, Amasino RM: PAFI-complex-mediated histone methylation of FLOWERING LOCUS C chromatin is required for the vernalization-responsive, winter-annual habit in Arabidopsis. Genes Dev 2004, 18:2774-2784.

18. Zhang H, Ransom C, Ludwig P, van Nocker S: Genetic analysis of early flowering mutants in Arabidopsis defines a class of pleiotropic developmental regulator required for expression of the flowering-time switch Flowering Locus C. Genetics 2003, 164:347-358.

19. Wood CC, Robertson M, Tanner G, Peacock WJ, Dennis ES, Helliwell CA: The Arabidopsis thaliana vernalization response requires a Polycomb-like protein complex that also includes VERNALIZATION INSENSITIVE 3. PNAS 2006, 103:| 463|-|4636.

20. Sung S, Amasino RM: Vernalization in Arabidopsis thaliana is mediated by the PHD finger protein VIN3. Nature 2004, 427:159-164.

21. Quesada V, Dean C, Simpson GG: Regulated RNA processing in the control of Arabidopsis flowering. Int J Dev Biol 2005, 49:773-780.

22. Jiang D, Yang W, He Y, Amasino RM: Arabidopsis relatives of the human lysine-specific demethylase I repress the expression of FWA and FLOWERING LOCUS C and thus promote the floral transition. Plant Cell 2007, 19:2975-2987.

23. He Y, Michaels SD, Amasino RM: Regulation of flowering time by histone acetylation in Arabidopsis. Science 2003, 302:175I-I754

24. Ausín I, Alonso-Blanco C, Jarillo JA, Ruiz-García L, Martínez-Zapater JM: Regulation of flowering time by FVE, a retinoblastomaassociated protein. Nat Genet 2004, 36:162-166.

25. Gogal GFW, Sheldon CC, Gubler F, Moritz T, Bagnall DJ, MacMillan CP, Li SF, Parish RW, Dennis ES, Weigel D, King RW: GAMYB-like genes, flowering, and gibberellin signaling in Arabidopsis. Plant Physiol 200I, I 27:1682-1693.

26. Jonkers $\mathrm{H}$ : On the flower formation, the dormancy and the early forcing of strawberries. In Thesis Mededelingen van de Landbouwhogeschool, Wageningen; 1965.

27. Heide $O$, Sønsteby $A$ : Interactions of temperature and photoperiod in the control of flowering of latitudinal and altitudinal populations of wild strawberry (Fragaria vesca). Physiol Plant 2007, 130:280-289.

28. Heide O: Photoperiod and temperature interactions in growth and flowering of strawberry. Physiol Plant 1977, 40:21-26.

29. Guttridge CG: Fragaria $\times$ ananassa. In CRC Handbook of Flowering Volume III. Edited by: Halevy A. Boca Raton: CRC Press; 1985:16-33.

30. Konsin M, Voipio I, Palonen P: Influence of photoperiod and duration of short-day treatment on vegetative growth and flowering of strawberry (Fragaria $\times$ ananassa Duch.). J Hort Sci Biotech 2001, 76:77-82.

3I. Hytönen T, Palonen P, Mouhu K, Junttila O: Crown branching and cropping potential in strawberry (Fragaria $x$ ananassa, Duch.) can be enhanced by daylength treatments. J Hort Sci Biotech 2004, 79:466-47I.

32. Darrow GM: The strawberry. History, breeding and physiology New York: Holt, Rinehart and Winston; 1966.

33. Durner EF, Barden JA, Himelrick DG, Poling EB: Photoperiod and temperature effects on flower and runner development in day-neutral, junebearing and everbearing strawberries. Amer Soc Hort Sci 1984, 109:396-400.

34. Sønsteby A, Heide OM: Long-day control of flowering in everbearing strawberries. J Hort Sci Biotech 2007, 82:875-884.

35. Sønsteby A, Heide OM: Long-day rather than autonomous control of flowering in the diploid everbearing strawberry Fragaria vesca ssp. semperflorens. J Hort Sci Biotech 2008, 83:360-366.

36. Albani M, Battey NH, Wilkinson MJ: The development of ISSRderived SCAR markers around the SEASONAL FLOWERING LOCUS (SFL) in Fragaria. Theor Appl Gen 2004, 109:57I-579. 
37. Guttridge CG: Further evidence for a growth-promoting and flower-inhibiting hormone in strawberry. Annals Bot 1959, 23:6|2-62|.

38. Thompson PA, Guttridge CG: Effect of gibberellic acid on the initiation of flowers and runners in the strawberry. Nature 1959, I 84:72-73.

39. Guttridge CG, Thompson PA: The effects of gibberellins on growth and flowering of Fragaria and Duchesnea. J Exp Bot 1963, I 5:631-646.

40. Brown T, Wareign PF: The genetic control of the everbearing habit and three other characters in varieties of Fragaria vesca. Euphytica 1965, I4:97-II2.

4I. Battey N, Miere P, Tehranifar A, Cekic C, Taylor S, Shrives K, Hadley $P$, Greenland A, Darby J, Wilkinson M: Genetic and environmental control of flowering in strawberry. In Genetic and Environmental Manipulation of Horticultural Crops Edited by: Cockshull KE, Gray D, Seymour GB, Thomas B. Wallingford, UK, Cab International; 1998: || |- -|3|.

42. Diatchenko L, Lau YF, Campbell AP, Chenchik A, Moqadam F, Huang B, Lukyanov S, Lukyanov K, Gurskaya N, Sverdlov ED, Siebert PD: Suppression subtractive hybridization: a method for generating differentially regulated or tissue-specific cDNA probes and libraries. PNAS 1996, 93:6025-6030.

43. Thomas B: Light signals and flowering. J Exp Bot 2006, 57:3387-3393

44. Stewart P: Molecular characterization of photoperiodic flowering in strawberry (Fragaria sp.). In PhD thesis University of Florida; 2007.

45. Fowler S, Lee K, Onouchi H, Samach A, Richardson K, Morris B, Coupland G, Putterill J: GIGANTEA: a circadian clock-controlled gene that regulates photoperiodic flowering in Arabidopsis and encodes a protein with several possible membranespanning domains. EMBO J I999, I 8:4679-4688.

46. Jang S, Marchal V, Panigrahi KCS, Wenkel S, Soppe W, Deng X, Valverde F, Coupland G: Arabidopsis COPI shapes the temporal pattern of $\mathrm{CO}$ accumulation conferring a photoperiodic flowering response. EMBO | 2008, 27:| 277-| 288.

47. Laubinger S, Marchal V, Le Gourrierec J, Wenkel S, Adrian J, Jang S, Kulajta C, Braun H, Coupland G, Hoecker U: Arabidopsis SPA proteins regulate photoperiodic flowering and interact with floral inducer CONSTANS to regulate its stability. Development 2006, I 33:3213-3222.

48. Cerdán PD, Chory J: Regulation of flowering time by light quality. Nature 2003, 423:88I-885.

49. Kang $X$, Zhou $Y$, Sun $X, N i$ M: HYPERSENSITIVE TO RED AND BLUE $I$ and its C-terminal regulatory function control FLOWERING LOCUS T expression. Plant J 2007, 52:937-948.

50. Scortecci KC, Michaels SD, Amasino RM: Identification of a MADS-box gene, FLOWERING LOCUS $M$, that repress flowering. Plant J 200I, 26:229-236.

51. Reeves PA, He Y, Schmitz RJ, Amasino RM, Panella LW, Richards CM Evolutionary conservation of the FLOWERING LOCUS Cmediated vernalization response: evidence from the sugar beet (Beta vulgaris). Genetics 2007, I 76:295-307.

52. Choi K, Park C, Lee J, Oh M, Noh B, Lee I: Arabidopsis homologs of components of the SWRI complex regulate flowering and plant development. Development 2007, I34:|93 |-194|

53. Kim KS, Choi K, Park C, Hwanga H, Lee I: SUPPRESSOR OF FRIGIDA4, encoding a C2H2-type zinc finger protein, represses flowering by transcriptional activation of Arabidopsis FLOWERING LOCUS C. Plant Cell 2006, I 8:2985-2998.

54. Folta KM, Staton M, Stewart PJ, Jung S, Bies DH, Jesudurai C, Main D: Expressed sequence tags (ESTs) and simple sequence repeat (SSR) markers from octoploid strawberry (Fragaria $\times$ ananassa). BMC Plant Biol 2005, 5:I2.

55. Levy YY, Mesnage S, Mylne JS, Gendall AR, Dean C: Multiple roles of Arabidopsis VRNI in vernalization and flowering time control. Science 297:243-246.

56. Mylne JS, Barrett L, Tessadori F, Mesnage S, Johnson L, Bernatavichute VN, Jacobsen SE, Fransz P, Dean C: LHPI, the Arabidopsis homologue of HETEROCHROMATIN PROTEINI, is required for epigenetic silencing of FLC. PNAS 2006, I 03:50I2-50I7.

57. Lee JH, Yoo SJ, Park SH, Hwang I, Lee JS, Ahn JH: Role of SVP in the control of flowering time by ambient temperature in Arabidopsis. Genes Dev 2007, 2 1:397-402.
58. Wagner D, Sablowski RWM, Meyerowitz EM: Transcriptional activation of APETALAI by LEAFY. Science 1999, 285:582-584.

59. Turck F, Fornara F, Coupland G: Regulation and identity of florigen: FLOWERING LOCUS T moves central stage. Annu Rev Plant Biol 2008, 59:573-594

60. Zagotta MT, Hicks KA, Jacobs Cl, Young JC, Hangarter RP, MeeksWagner D: The Arabidopsis ELF3 gene regulates vegetative photomorphogenesis and the photoperiodic induction of flowering. Plant J 1996, 10:691-702.

6I. Weebadde CK, Wang D, Finn CE, Lewers KS, Luby JJ, Bushakra J, Sjulin TM, Hancock JF: Using a linkage mapping approach to identify QTL for day-neutrality in the octoploid strawberry. Plant Breed 2008, I 27:94-101.

62. Ahmadi H, Bringhurst RS, Voth V: Modes of inheritance of photoperiodism in Fragaria. J Amer Soc Hort Sci 1990, I I 5: I 46-452.

63. Shulaev V, Korban SS, Sosinski B, Abbott AG, Aldwinckle HS, Folta KM, lezzoni A, Main D, Arús P, Dandekar AM, Lewers K, Brown SK, Davis TM, Gardiner SE, Potter D, Veilleux RE: Multiple models for Rosaceae genomics. Plant Physiol 2008, I 47:985-1003.

64. Takada S, Goto K: Terminal flower 2, an Arabidopsis homolog of heterochromatin protein I, counteracts the activation of Flowering locus $T$ by Constans in the vascular tissues of leaves to regulate flowering time. Plant Cell 2003, I 5:2856-2865.

65. Sawa M, Nusinow DA, Kay SA, Imaizumi T: FKFI and GIGANTEA complex formation is required for day-length measurement in Arabidopsis. Science 2007, 3 I 8:26।-265.

66. Hecht V, Foucher F, Ferrandiz C, Macknight R, Navarro C, Morin J, Vardy ME, Ellis N, Beltran J, Rameau C, Weller JL: Conservation of Arabidopsis flowering genes in model legumes. Plant Physiol 2005, I37:|420-|434.

67. Alabadi D, Oyama T, Yanovsky MJ, Harmon FG, Mas P, Kay SA Reciprocal regulation between $\mathrm{TOCI}$ and $L \mathrm{HY} / \mathrm{CCAI}$ within the Arabidopsis circadian clock. Science 200I, 293:880-883.

68. Böhlenius $\mathrm{H}$ : Control of flowering time and growth cessation in Arabidopsis and Populus trees. In PhD thesis Swedish University of Agricultural Sciences, Umeå; 2008.

69. Wang R, Farrona S, Vincent C, Joecker A, Schoof H, Turck F, AlonsoBlanco C, Coupland G, Albani MC: PEPI regulates perennial flowering in Arabis alpina. Nature 2009, 459:423-427.

70. Zhang X, Clarenz O, Cokus S, Bernatavichute YV, Pellegrini $M$ Goodrich J, Jacobsen SE: Whole genome analysis of histone $\mathbf{H 3}$ Iysine 27 trimethylation in Arabidopsis. PloS Biol 2007, 5:el 29.

7I. Yano M, Katayose Y, Ashikari M, Yamanouchi U, Monna L, Fuse T, Baba T, Yamamoto K, Umehara Y, Nagamura Y, Sasaki T: HdI, a major photoperiod sensitivity quantitative trait locus in rice, is closely related to the Arabidopsis flowering time gene CONSTANS. Plant Cell 2000, I 2:2473-2484.

72. Sargent DJ, Clarke J, Simpson DW, Tobutt KR, Arús P, Monfort A Vilanova S, Denoyes-Rothan B, Rousseau M, Folta KM, Bassil NV, Battey $\mathrm{NH}$ : An enhanced microsatellite map of diploid Fragaria. Theor Appl Genet 2006, I I 2: I 349-I359.

73. Roberts AV, Blake PS, Lewis R, Taylor JM, Dunstan DI: The effect of gibberellins on flowering in roses. J Plant Growth Regul 1999, 18:113-119.

74. Monte D, Somerville S: Pine tree method for isolation of plant RNA. In DNA microarrays: a molecular cloning manual Edited by: Bowtell D, Sambrook J. New York: Cold Spring Harbour Laboratory Press; 2002:124-126.

75. Laitinen RAE, Immanen J, Auvinen P, Rudd S, Alatalo E, Paulin L, Ainasoja M, Kotilainen M, Koskela S, Teeri TH, Elomaa P: Analysis of the floral transcriptome uncovers new regulators of organ determination and gene families related to flower organ differentiation in Gerbera hybrida (Asteraceae). Genome Res 2005, I 5:475-486.

76. Tuskan GA, DiFazio S, Jansson S, Bohlmann J, Grigoriev I, et al.: The genome of black cottonwood, Populus trichocarpa (Torr. \& Gray). Science 2006, 3 I3:1596-1604.

77. Childs KL, Hamilton JP, Zhu W, Ly E, Cheung F, Wu H, Rabinowicz PD, Town CD, Buell CR, Chan AP: The TIGR plant transcript assemblies database. Nucleic Acids Res 2007, 35:D846-D85।.

78. Mockler T, Yang H, Yu X, Parikh D, Cheng Y, Dolan S, Lin C: Regulation of photoperiodic flowering by Arabidopsis photoreceptors. PNAS 2003, I 00:2 140-2। 45.

79. Guo HW, Yang WY, Mockler TC, Lin CT: Regulation of flowering time by Arabidopsis photoreceptors. Science 1998 , 279: $1360-1363$ 
80. Kim W, Fujiwara S, Suh S, Kim J, Kim Y, Han L, David K, Putterill J, Nam HG, Somers DE: ZEITLUPE is a circadian photoreceptor stabilized by GIGANTEA in blue light. Nature 2007 449:356-360.

81. Kim D, Kang J, Yang S, Chung K, Song P, Park C: A phytochromeassociated protein phosphatase $2 \mathrm{~A}$ modulates light signals in flowering time control in Arabidopsis. Plant Cell 2002, I 4:3043-3056.

82. Staiger D, Allenbach L, Salathia N, Fiechter V, Davis SJ, Millar AC, Chory J, Fankhauser C: The Arabidopsis SRRI gene mediates phyB signaling and is required for normal circadian clock function. Genes Dev 2003, 17:256-268.

83. Hazen SP, Schultz TF, Pruneda-Paz JL, Borevitz JO, Ecker JR, Kay SA LUX ARRHYTHMO encodes a myb domain protein essential for circadian rhythms. PNAS 2005, 102:10387-10392.

84. Doyle MR, Davis SJ, Bestow RM, McWatters HG, Kozma-Bognar L, Nagy F, Millar AJ, Amasino MR: The ELF4 gene controls circadian rhythms and flowering time in Arabidopsis thaliana. Nature 2002, 419:74-77.

85. Nakamichi N, Kita M, Niinuma K, Ito S, Yamashino T, Mizoguchi T, Mizuno T: Arabidopsis clock-associated pseudo-response regulators PRR9, PRR7 and PRR5 coordinately and positively regulate flowering time through the canonical CONSTANS dependent photoperiodic pathway. Plant Cell Physiol 2007, 48:822-832

86. Noh B, Lee $\mathrm{S}$, Kim H, Yi G, Shin E, Lee M, Jung KMR, Doyle KMR, Amasino RM, Noh Y: Divergent roles of a pair of homologous jumonji/zinc-finger-class transcription factor proteins in the regulation of Arabidopsis flowering time. Plant Cell 16:260I-2613.

87. Hanzawa $\mathrm{Y}$, Money $\mathrm{T}$, Bradley $\mathrm{D}$ : A single amino acid converts a repressor to an activator of flowering. PNAS 2005 102:7748-7753.

88. Chen M, Ni M: RFI2, a RING-domain zinc finger protein, negatively regulates CONSTANS expression and photoperiodic flowering. Plant J 2006, 46:823-833

89. Cai X, Ballif J, Endo S, Davis E, Liang M, Chen D, DeWald D, Kreps J, Zhu T, Wu Y: A putative CCAAT-binding transcription factor is a regulator of flowering timing in Arabidopsis. Plant Physiol 2007, I 45:98-105

90. Pien S, Fleury DF, Mylne JS, Crevillen P, Inzé D, Avramova Z, Dean C, Grossniklaus U: ARABIDOPSIS THITHORAXI dynamically regulates FLOWERING LOCUS C activation via histone 3 lysine 4 trimethylation. Plant Cell 2008, 20:580-588.

91. Zhang $\mathrm{H}$, van Nocker S: The VERNALIZATION INDEPENDENCE 4 gene encodes a novel regulator of FLOWERING LOCUS C. Plant J 2002, 3 1:663-673.

92. Gendall AR, Levy YY, Wilson A, Dean C: The VERNALIZATION 2 gene mediates the epigenetic regulation of vernalization in Arabidopsis. Cell 200I, 107:525-535.

93. Chanvivattana $Y$, Bishopp A, Schubert D, Stock C, Moon $Y$, Sung ZR, Goodrich J: Interaction of Polycomb-group proteins controlling flowering in Arabidopsis. Development 2004, I 3 I:5263-5276.

94. MacKnight R, Bancroft I, Page T, Lister C, Schmidt R, Love K, Westphal L, Murphy G, Sherson S, Cobbett C, Dean C: FCA, a gene controlling flowering time in Arabidopsis thaliana encodes a protein containing RNA binding domains. Cell 1997, 89:737-745

95. Schomburg FM, Patton DA, Meinke DW, Amasino RM: FPA, a gene involved in floral induction in Arabidopsis thaliana, encodes a protein containing RNA-recognition motifs. Plant Cell 200I, 13:| 427-|436.

96. Lim MH, Kim J, Kim YS, Chung KS, Seo YH, Lee I, Kim J, Hong CB, Kim HJ, Park CM: A new Arabidopsis thaliana gene, FLK encodes a RNA binding protein with $K$ homology motifs and regulates flowering time via FLOWERING LOCUS C. Plant Cell 2004, 16:73|-740.

97. Simpson GG, Dijkwel PP, Quesada V, Henderson I, Dean C: $\mathbf{F Y}$ is a RNA 3'end-processing factor that interacts with FCA to control the Arabidopsis thaliana floral transition. Cell 2003, I I 3:777-787.

98. Wang X, Zhang Y, Ma Q, Zhang Z, Xue Y, Bao S, Chong K: SKB I. mediated symmetric dimethylation of histone H4R3 controls flowering time in Arabidopsis. EMBO J 2007, 26: I934- 1941.

99. Lee I, Aukerman MJ, Gore SL, Lohman KN, Michaels SD, Weaver LM John MC, Feldmann KA, Amasino RM: Isolation of LUMINIDE-
PENDENS: a gene involved in the control of flowering time in Arabidopsis thaliana. Plant Cell 1994, 6:75-83.

100. Cheng H, Qin L, Lee S, Fu X, Richards DE, Cao D, Luo D, Harberd NP, Peng J: Gibberellin regulates Arabidopsis floral development via suppression of DELLA protein function. Development 2004, 13 I:1055-1064.

I0I. Tseng TS, Salomé PA, McClung CR, Olszewski NE: SPINDLY and GIGANTEA interact and act in Arabidopsis thaliana pathways involved in light responses, flowering and rhythms in leaf movements. Plant Cell 2004, 16:1550-1563.

102. Magome H, Yamaguchi S, Hanada A, Kamiya Y, Oda K: Dwarf and delayed-flowering I, a novel Arabidopsis mutant deficient in gibberellin biosynthesis because of overexpression of putative AP2 transcription factor. Plant J 2004, 37:720-729.

103. Kania T, Russenberger D, Peng S, Apel K, Melzer S: FPFI promotes flowering in Arabidopsis. Plant Cell 1997, 9:1327-1338.

104. Aukerman MJ, Sakai H: Regulation of flowering time and floral organ identity by a microRNA and its APETALA2-like target genes. Plant Cell 2003, I5:2730-274I.
Publish with Biomed Central and every scientist can read your work free of charge

"BioMed Central will be the most significant development for disseminating the results of biomedical research in our lifetime. "

Sir Paul Nurse, Cancer Research UK

Your research papers will be:

- available free of charge to the entire biomedical community

- peer reviewed and published immediately upon acceptance

- cited in PubMed and archived on PubMed Central

- yours - you keep the copyright
BioMedcentral 